\title{
Balneoclimateric Resort Malnaş-Bãi
}

\section{Munteanu Constantin ${ }^{1}$}

\section{${ }^{1}$ Institutul ${ }^{1}$ National Institute of Rehabilitation, Physical Medicine and Balneoclimatology}

Bucharest;

Geographical area : Baraolt Mountains, Bodoc

Region : mountain

The basin / river / spring: Olt

Location: The Olt Defile,

Forest Massif (1213 m altitude)

Natural resources :

- mineral springs (carbonated, alkaline, bicarbonate, calcium, magnesium, ferruginous, sodium)

- bioclimate of sparing

- mud

- mofettes

Internal cure :

- Maria Spring (sodas, ferruginous, iodine, bicarbonate, chloride, sodium, calcium ,isotonic,athermic (most used) water) indicated in digestive disorders (dyspepsia and hyperacidity, chronic gastritis, chronic gastric and duodenal ulcers, chronic colitis, chronic constipation)

- (biliary dyskinesia, chronic calculated not and calculated cholecystitis chronic hepatitis, chronic pancreatitis).

- renal

- metabolosm and nutrition (goute, diabete)

- gastrointestinal

External cure:

-Hercules Spring supplies cold baths and

is indicated in diseases of the cardiovascular system compensated (compensated mitral and aortic, hypertension, peripheral arterial disease in atherosclerosis)

diseases)

- gynecological (only in associated

- asthenic neurosis

- respiratory

Observations:

- Spring: Principal, Victoria, Mioara, Izvorul from Grota, Izvorul of Dobola, Bore Siculia, Maria, Hercules, Izvorul from Baile Calde

Season : may- september

Climate : cold mountain area
The Malnas village residence of Malnas is situated on the banks of Olt River, between the Baraolt Mountains and the Bodoc Mountains, along the national road $\mathrm{E}$ to 575 (DN-12). It has railway station on the line 400, and MalnasResort has its own station. It is $17 \mathrm{~km}$ from Saint -George. Form an administrative unit with Malnas-Spa, resort located $3 \mathrm{~km}$ from the village Malnas and Zălan Valley area, isolated in the heart of the Baraolt Mountains, 10 $\mathrm{km}$ of common residence. Today is upgrading the link road from Zălan Malnas Valley .

Malnas Bai is located on the right bank of the river Olt, in a beautiful valley at the foothills of Baraolt and Bodoc Mountains and at an altitude of 505 meters and $22 \mathrm{~km}$ away from St. George. The area is very rich in mineral water springs and springs with therapeutic values .The resort began to grow in a period when was administrated by the Semsey family. Since 1865 the resort is famous and has many visitors. The resort enjoys a temperate continental climate with relatively humid air masses. The average temperature ranges between 7-8 degrees Celsius. Bai Malnas is recommended for the treatment of digestive diseases (chronic gastritis, ulcers), liver (hepatitis, cholecystitis, chronic pancreatitis), cardio-vascular disease (arterial disease, chronic heart disease, hypertension).

Malnas village name is mentioned in writing for the first time in 1366 (Malnas). In 1690 appears as Malnas. Zălan Valley is a town younger, being recorded for the first time in 1740 , as the Zalányi Evegcsür. Bathrooms Malnas City was formed in mid-nineteenth century.

Literature knowns artifacts of bronze and iron age found on the village Malnas. Herecz plateau above the village are the ruins of medieval fortress Herecz. Following archaeological excavations within the city were found a silver dinar during the Hungarian king András II, enabling the city dating to late eighteenth century - the beginning of the 
eighteenth century. From borders of the village Malnas were unearthed ceramics from Neolithic era . Ciuc Depression oriented towards the Roman road has followed river Olt. Malnas village near in the territory of present village Olteni, there was a Roman military camp (a castrum). Territory of the Valley Zălanului village was a wooded area, which in 1692 belonged to the city Zălan having Egyedmezeje name. In 1694 CrisValley Kalnoky family built a factory glass here, which was the first factory of its kind in Transylvania. In this factory has made stained glass windows of St. Michaelchurch in Cluj and the Black Church in Brasov. In 1860 the factory was destroyed by fire and not rebuilt. Some products of the factory are kept in the National Szekler Museum other locals in personal colacția Karácsony Zoltán.

In 1873 it formed an association for the rational use of the common wealth: mineral water springs, and gas therapeutic properties. In 1891 were built bathrooms with hot water, in 1896 a soda factory and operated since 1904 and amineral water bottling point. Since 1907 this concern was taken over by Siculia SA association.

At the end of the nineteenth century, in the north of the village Malnas were opened a quarry, where andesite rocks were extracted used in construction. As a result developed and stone carving. During the interwar period, but also between the years 1950-1989, MalnasResort baths, mineral water bottling unit and carb onated acid were sources of income for locals. In the village has functioned a sanatorium, which used water sources Ilona, Mioara, Central, Victoria and central fountain. Unfortunately, after the 1989 regime change, the bathrooms have becomederelict. Now it is bottled only mineral water "Pearl Covasna" and the carbonated acid.

Currently Malnas population deals with agriculture, livestock and forest exploitation. The last two characterized Zălan Valley village economy. In this village agricultural products, wood and feed are used in trade. In this town there are numerous springsand alkaline salt (Anas, Bugyogó, Karácsony, Csuklyoni, Nadas, Kerkedombi,etc.). Everywhere the basement is rich in carbon dioxide ready to be tapped. In the Teks water stream from Zălan Valley, live trouts and often we can see in quiet places black storks.
The Malnas village has become a independent common only in 2004, when it detached from the ancient common who resided in Micfalau village.

Village population, according to the 2002 census counted 1202 people, of which 550 were counted in Malnas, 503 in Malnas-Bai and 149 people in the Zălan Valley. Ethnic composition is: $5.90 \%$ Romanian, $93.59 \%$ Magyars and $0.33 \%$ Gypsy. A person is declared German. Malnas has original possibilities in terms of spa industry, production of bottled mineral water, stones for construction and operation of harvesting the potential tourism. In the village was set up a mechanized ski. The region has a dense network of marked trails. In Reformedand Catholic churc $\mathrm{h}$ are preserved historical monuments. At Malnas -baths are the most valuable industrial monument of the region: a number of bottling plants, built in 1863, which is still running. Catholic Church from Zălan Valley was built in 1863,dedicated to the Virgin Mary. The church bell dates from 1750 .

\section{Administrative status: MALNAȘ Commune}

With the subsequent village :

- MICFALAU Village - commune

residence

- BIXAD Village - at $6 \mathrm{~km}$ from the residence

-MALNAS Village - at5 $\mathrm{km}$ from the residence

-MALNAS BAI - at $3 \mathrm{~km}$ from the residence

- ZALAN Valley - at $7 \mathrm{~km}$ on the hill and $36 \mathrm{~km}$ on the road

Geographical location: the village Malnas is located in the northernmost of the Covasna county, at the border with Harghita county, to cardinal point; 45.6. Neighboring localities are: Tusnad Bai climatic spa resort on the north, to the northwest Turia village, on the east village Cernat and Albis, south-east Bodoc village, west village Batan.

Relief: Malnas common is between Malnas Tusn ad reliefs, the central part of the village located in the cavity from to Bixad depression, with heights between $570-650 \mathrm{~m}$.

In the western part of the village lies the northern group of BODOC mountains with heights of $1200 \mathrm{~m}$ and the creek tip of Piliske on the south west. Great Murgul (1016) and Zalan Valley are placed along the Teks river and issurrounded by the high peaks of Baraolt mountains with $800 \mathrm{~m}$. 
Natural resources: the village is very rich and interesting, are large reserves of andesite, which are exploited in the quarries that lie along the village.

It is very rich in mineral water springs and healing springs values due to high mineralization water, the area represents aggression against metal and concrete.

Climate: The village has a temperate continental climate with relatively humid air masses. The average temperature is between 78 gr.C.

Economic potential: Malnas commune has a great economic potential. Until 2000, when he began the privatization process, the active population was 1920 persons, of which 1681 employed, after the dismissal of staff, the number of people employed decreased.

Citizens find jobs to SC, located in the Malnas commune and newly created small and medium enterprises. Joint stock companies with a staff under 50, with operating profile of the stone are: SC LAFARGE SA, with sections of career-Bixad Micfalau 65 workers, SC ROMACO Micfalau SA-sector career, with a total of 26 workers, SC PROD ELSCO 94 Bucharest, with a total of 20 workers, SC Liquor Malnas BAI SA, with 18 employees, S.C. Perla Covasnei SA, with a total of 36 employees, cooperative Olt Malnas BAI, under reorganization, Micfalau consumer cooperative, with 12 employees.

At the level of commune operate 34 small companies with business profile, with shops and mixed bars. Citizens, especially pensioners deals with stone processing and carving, based on the AUTHORISATION issued under Law $54 / 1991$.

The, medical assistance of the commune is provided by clinics with family doctors . The APOLLONIA LLC company, provides by pharmacy the necessary medication of population. After the increasing of the number of unemployed people, the City Hall of Malnas commune, has allocated social support from the local budget during the winter. The number of people with disabilities and social problems, is increasing.

Agriculture: the particularities of soil fertility, climatic vagaries and needs of the people, have led farmers to be looking for new elements in agricultural practice, which applied with skill to pluck the fruit of these lands.

Total area of the land: existing surface 6131 ha, of which 1701 ha arable, 1823 meadow ha, 2460 ha communal pastures, 85 ha orchards and 54 ha built, the main crops are potatoes, sugar beets, corn and cereal straw.

Services: from the number of service stations 12 are cooperatives: 3 with PTTR profile; in the Malnas commune there are private units for cars repair, hairdressing, transportation services.

Healthcare: in the Malnas commune Micfalau, Bixad, Malnas Village there are medical facilities (medical clinics). In Malnas there is a private dental practice, in Micfalau is a pharmacy SC APOLLONIA LLC, which provides medical treatment in villages belonging.

Tourism: is not fully exploited. For those who visit the villages there areaccommodation places:

\begin{tabular}{|c|c|c|c|}
\hline Localitatea & Forma de cazare & Nr. locuri & \\
\hline MALNAŞ BAI & HOTELUL OLT & 120 & 2 stele \\
\hline Vilele & Care nu corespund & & \\
\hline Bixad & MOTELUL HOTAR & 40 & \\
\hline & Pensiunea ANA & 10 & 1 margareta \\
\hline & $\begin{array}{c}\text { Pensiunea ŞURA } \\
\text { MARE }\end{array}$ & 9 & 1 margareta \\
\hline & Pensiunea Juli & 10 & 2 margareta \\
\hline & Pensiunea Szekely & 10 & 1 margareta \\
\hline
\end{tabular}

\section{MALNAS BAI BALNEOCLIMATERIC RESORT}

It is located on the right bank of the Olt River near the Bodoc Mountains. The resort has been formed in 1759, and since 1800 are known free pools.

The resort began starts to develop in the period when Semsey family manage; from 1865 the resort has well known and a lot of visitors. To exploit natural mineral has been formed Reszvenytarsasag Sikulia Society, who put in operation Szikulia springs and in the basement $\mathrm{CO} 2$ bottling. Grand Gyula, merchant from Brasov, starts the bottling line of Mary spring. Mineral water bottling, and currently operate as the SCPerla Covasnei S.A.

\section{The analysis report of MARIA Mineral} water was prepared based on analysis carried ou by LIAMNT laboratory (Laboratory Testing Therapeuticmineral waters and sludges) of INRMFB.

In hydrological terms, in Malnas area there are two overlapping aquifers, one -lower stuck in the cracks system and the fractured areas of limestone-gaseous formations, with Cretaceous age and the other - superior -in covering granular deposit sand with Policen Quaternary age. 
Vol.2, Nr.1, 2011

Policen-Quaternary

hidrostructure

belongs Ileana, Mioara, Bai Calde sources, wells No. 8 and 9 ISPIF exploited for therapeutic purposes, while from Cretaceous deposits hidrostructure are related to Mary, Principal, sources from wells 2, 1, 4, 10-11, 801-802, used for bottling.

Maria mineral water is a bicarbonate, chloride, sodium, carbonated, hypotonia water, used for internal treatment and bottling .

Maria Medicinal mineral water is bottled since 904 when it was recommended to treat various digestive disorders such as digestive disorders

(hyperacidity chronic gastritis, gastric and duodenal \ulcers, chronic colitis, chronic constipation), hepatobiliary actions (dyskinesia, chronic hepatitis, chronic pancreatitis, chronic cholecystitis not calculated or calculated), associated diseases: neurasthenia, headaches, mood disorders. The findings of this study reveals that Mary mineral water mineralization has changed in the past 20 years, both in terms of anion and cation. Significant increases in acid and sodium carbonateions, but also decreases magnesium and iron.

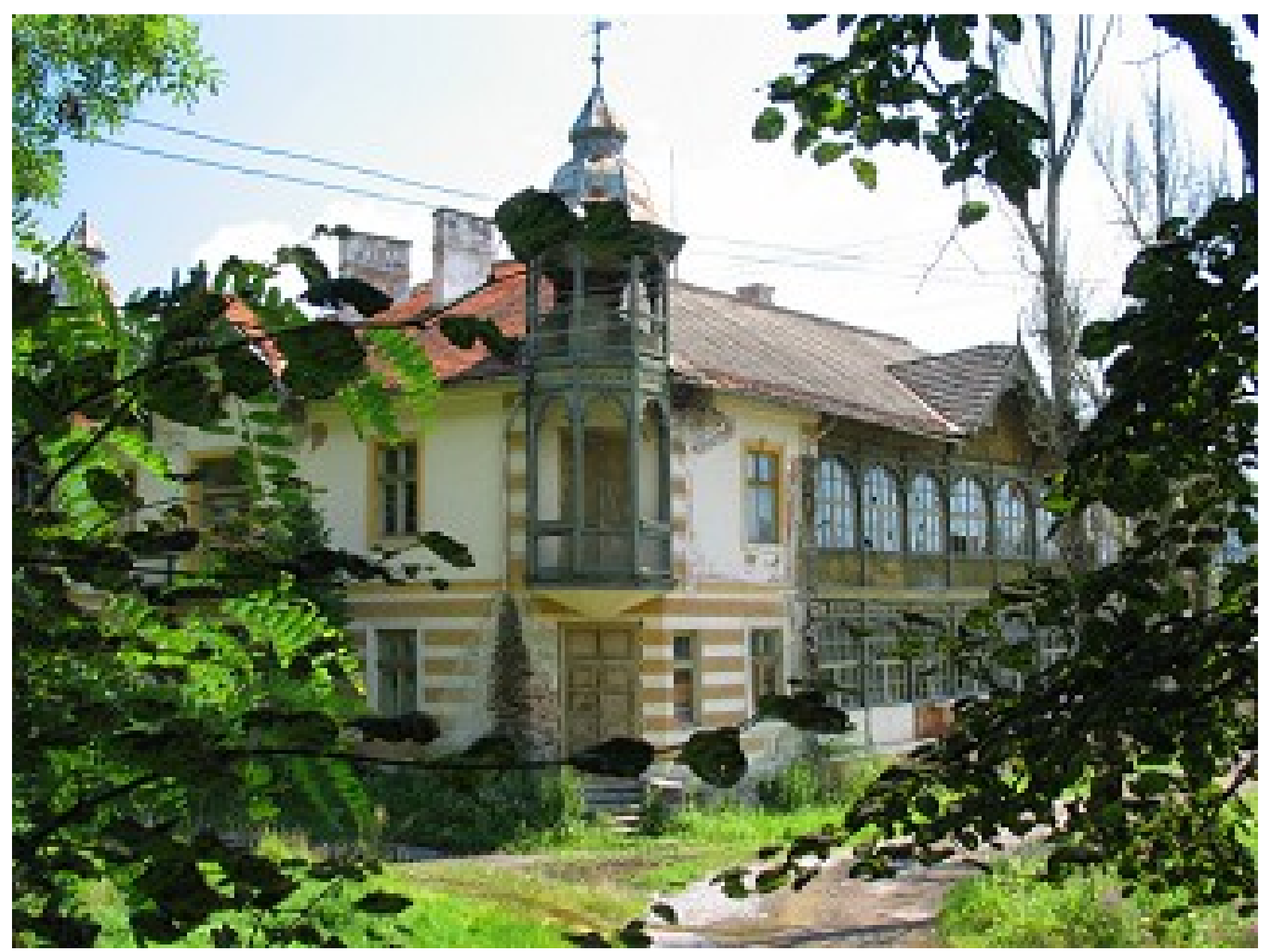

Photo 1 -Malnaş-Bãi Balneoclimateric Resort

( http://www.covasna.insse.ro/main.php?id=407) 